\title{
SKUTECZNOŚĆ JAKO DETERMINANTA DZIAŁAŃ ORGANÓW JEDNOSTEK SAMORZĄDU TERYTORIALNEGO
}

\section{Wprowadzenie}

Działanie administracji samorządowej może być analizowane w wielopłaszczyznowych obszarach jej funkcjonowania oraz według różnorakich kryteriów. Jednym z nich, określonym przez ustawodawcę w kontekście wskazania przesłanki ustanowienia zarządu komisarycznego, jest skuteczność. Brak doprecyzowania tego pojęcia przez ustawodawcę skutkuje pojawieniem się zróżnicowanych aspektów jego interpretacji w odniesieniu do funkcjonowania samorządu terytorialnego. W efekcie, badając kryterium skuteczności, można je odnieść do podstaw prawnych, w oparciu o które samorząd terytorialny prowadzi swoją działalność. Kwestię skuteczności można również analizować pod względem formowania struktur organizacyjnych i wskazywać jej rolę w ocenie działalności organów i samorządowych jednostek organizacyjnych. Wreszcie można rozpatrywać skuteczność w obszarze wykonywania zadań publicznych, na co wskazuje sam ustawodawca w przepisach dotyczących ustanawiania zarządu komisarycznego. Rozważania zawarte w niniejszym opracowaniu będą skupiały się właśnie wokół ostatniej kwestii związanej z analizą osiągania skuteczności w wykonywaniu zadań publicznych. W związku z powyższym podjęte $\mathrm{w}$ niniejszej publikacji wnioskowania oparte zostaną na wykładni językowej oraz wykładni celowościowej, których wynik umożliwi dokonanie oceny: w jakim stopniu „skuteczność” determinuje

* Dr, Katolicki Uniwersytet Lubelski Jana Pawła II; e-mail: kisala@kul.lublin.pl, ORCID ID: https:/ / orcid.org/0000-0003-4593-0394. 
podejmowanie i wykonywanie zadań publicznych przez organy jednostek samorządu terytorialnego oraz jakie są skutki jej braku.

\section{Kryterium skuteczności - rozważania terminologiczne}

Zgodnie z ujęciem W. Dawidowicza działania są sprawne, jeżeli prowadzą do określonego celu, przy możliwie najmniejszych nakładach energii i środków. Działanie sprawne to działanie skuteczne i szybkie ${ }^{1}$. Skuteczność wiąże się więc z ukierunkowaniem działania na realizację określonego celu i odnosi się do stopnia w jakim założone cele zostały osiągnięte ${ }^{2}$. Skuteczność podlega zatem stopniowaniu - może być większa lub mniejsza w zależności od tego, czy cel został osiągnięty, czy też zdołano zbliżyć się do celu tylko do pewnego stopnia3. Skuteczność można więc określić jako relację zgodności uzyskanego wyniku zakończonego działania z celem określonym dla tego działania ${ }^{4}$. Cel rozumiany jest jako stan rzeczywistości, do którego podmiot chce doprowadzić poprzez działanie. Różnica pomiędzy celowością a skutecznością dotyczy momentu rozpatrywania wyniku działania. W przypadku skuteczności ocena jest dokonywana po wykonaniu czynności, a w przypadku stosowania pojęcia celowości dotyczy ona planowanych działań. Ocena skuteczności jest zatem uwarunkowana formułą celu. Jeżeli cel ma cechy mierzalne, organizacja ma możliwość sprawnej oceny skuteczności jego realizacji ${ }^{5}$.

Cel jest wytyczną zakodowaną w przepisach prawa, której urzeczywistnienie jest obowiązkiem organów samorządowych. Prawo wyznacza

1 Zob. W. Dawidowicz, Zagadnienia ustroju administracji państwowej w Polsce, Warszawa 1970, s. 53.

2 Zob. T. Lubińska i in., Budżet zadaniowy w Polsce - istota, struktura, metodyka, [w:] T. Lublińska (red.), Nowe zarządzanie publiczne - skuteczność i efektywność. Budżet zadaniowy w Polsce, Warszawa 2009, s. 56.

3 Zob. T. Kotarbiński, Traktat o dobrej robocie, Wrocław-Warszawa-Kraków-Gdańsk 1975 , s. 457.

4 Zob. T. Pszczołowski, Celowość, skuteczność i efektywność, „Prakseologia” 1977, nr 3, s. $5-13$.

5 Zob. M. Sułkowski, R. Wolniak, Przegląd stosowanych metod oceny skuteczności i efektywności organizacji zorientowanych na ciagłe doskonalenie, "Zeszyty Naukowe Politechniki Śląskiej" Organizacja i Zarządzanie 2013, z. 67, s. 64. 
granice działania, z którymi wiążą się określone cele oraz tworzy narzędzia służące ich realizacji. Wyodrębnienie jednostki samorządowej następuje z uwzględnieniem więzi społecznych, gospodarczych, kulturowych oraz $\mathrm{w}$ sposób zapewniający jednostkom terytorialnym zdolność wykonywania zadań publicznych. Głównym celem jednostki samorządowej jest zaspokajanie potrzeb mieszkańców wspólnot samorządowych poprzez świadczenie usług powszechnie dostępnych. Na jednostce samorządowej danego szczebla ciąży więc obowiązek wykonywania zadań wskazanych w ustawach ustrojowego oraz materialnego prawa administracyjnego. Legalność stanowi podstawę skuteczności działania i wyznacza jego granice.

\section{Legalność jako podstawa skuteczności działania}

Fundamentalnymi zasadami, na podstawie których samorząd terytorialny wykonuje zadania publiczne są: zasada decentralizacji oraz zasada pomocniczości. Jak słusznie zauważa A. Szpor, subsydiarność jest wyznacznikiem dla ustawodawcy zwykłego w przedmiocie tworzenia ram instytucjonalnych wspólnot pośrednich oraz podziału kompetencji pomiędzy rząd i samorząd ${ }^{6}$. Obie zasady wykluczają hierarchiczne podporządkowanie, o którym można mówić w dwóch konfiguracjach: pierwsza dotyczy relacji samorząd terytorialny-administracja rządowa, druga natomiast odnosi się do relacji pomiędzy jednostkami samorządu terytorialnego rożnego szczebla. Brak hierarchicznego podporządkowania pomiędzy administracją rządową a samorządem terytorialnym przekłada się na samodzielność jednostek samorządowych w wykonywaniu zadań publicznych, o charakterze lokalnym bądź wojewódzkim (regionalnym), których celem jest zaspokojenie potrzeb danej wspólnoty samorządowej. Zadania te dotyczą infrastruktury społecznej, infrastruktury technicznej, bezpieczeństwa i porządku publicznego, ładu przestrzennego i ekologicznego, rozwoju gospodarczego, współpracy międzynarodowej. Zakres

6 Zob. A. Szpor, Państwo a subsydiarność jako zasada prawa w UE i w Polsce, „Samorząd Terytorialny" 2001, nr 1/2, s. 18-19.

7 Zob. B. Jaworska-Dębska, Zadania samorzadu terytorialnego, [w:] M. Stahl (red.), Prawo administracyjne. Pojęcia, instytucje, zasady w teorii i orzecznictwie, Warszawa 2019, 
tych zadań odnosi się do określonego terytorium, charakteryzującego się uwarunkowaniami społecznymi, naturalnymi, kulturowymi. Każda jednostka samorządowa dostosowuje sposób wykonania oraz zakres zadania wynikającego z ustaw, do warunków panujących na jej terenie ${ }^{8}$. Stąd, nawet jeśli zadania jednostki samorządu terytorialnego określone są w ustawach w sposób jednorodny, to zakres podejmowanych działań zależy już od samodzielnej decyzji każdej jednostki samorządu terytorialnego, z zastrzeżeniem, że działa ona na podstawie i w granicach prawa. Zasada pomocniczości zakłada odpowiedzialność jednostki za zaspokajanie swoich potrzeb. Jednocześnie przewiduje, w przypadku gdy jednostka nie jest w stanie swoich potrzeb zaspokoić, interwencję społeczności czy wspólnot. Dopiero gdy tego typu interwencja nie będzie skuteczna, wkracza organ władzy publicznej. Zasada ta uzasadnia podejmowanie działań na szczeblu ponadlokalnym, jeśli:

rozwiązanie takie okaże się lepsze i bardziej skuteczne aniżeli działania organów wspólnot szczebla podstawowego. Zasada pomocniczości powinna być jednak rozumiana w całej swej złożoności, która polega na tym, że umacnianie uprawnień obywateli i ich wspólnot wymaga wszelkiego rodzaju działań podejmowanych przez organy jednostek samorządu kolejnych szczebli, jak również przez organy administracji rządowej, jeżeli rozwiązanie problemów przez organy samorządu terytorialnego nie jest możliwe (skuteczne) i ewidentnie zagrożone jest wykonywanie zadań publicznych służące zaspokajaniu zbiorowych potrzeb lokalnej wspólnoty samorządowej9.

Zasada pomocniczości dopuszcza możliwość interwencji wyższego szczebla tylko wówczas, kiedy szczebel niższy nie jest w stanie skutecznie rozwiązać określonego problemu ${ }^{10}$. Odniesienie do zasady pomocniczości

s. $495-496$.

8 Zob. A. Wiktorowska, Samorzad terytorialny, [w:] J. Jagielski, M. Wierzbowski (red.), Prawo administracyjne, Warszawa 2019, s. 284.

9 Wyrok Naczelnego Sądu Administracyjnego (NSA) z dnia 26 października 2016 r., II OSK 2347/16, Centralna Baza Orzeczeń Sądów Administracyjnych (CBOSA); zob. wyrok Trybunału Konstytucyjnego (TK) z dnia 18 lutego 2003 r., K 24/02, OTK ZU 2003, nr 2A, poz. 11.

10 Zob. M. Górski, Zasada subsydiarności a zakres kompetencji w ochronie środowiska, [w:] E. Ura (red.), Granice samodzielności wspólnot samorządowych. Międzynarodowa Konferencja Naukowa, Baranów Sandomierski 22-25 maja 2005 r., Rzeszów 2005, s. 78. 
zostało także podkreślone w Europejskiej Karcie Samorządu Lokalnego ${ }^{11}$, sporządzonej w Strasburgu dnia 15 października 1985 r., która podkreśla $\mathrm{w}$ preambule prawo obywateli do uczestnictwa w kierowaniu sprawami publicznymi. Prawo to właśnie na szczeblu lokalnym może być realizowane w sposób najbardziej bezpośredni. Ponadto istnienie społeczności lokalnych wyposażonych $\mathrm{w}$ rzeczywiste uprawnienia stwarza warunki dla zarządzania skutecznego i pozostającego zarazem $\mathrm{w}$ bezpośredniej bliskości obywatela. Zgodnie z art. 4 ust. 3 EKSL generalnie odpowiedzialność za sprawy publiczne powinny ponosić przede wszystkim te organy władzy, które znajdują się najbliżej obywateli. Powierzając te funkcje innemu organowi władzy, należy uwzględnić zakres i charakter zadania oraz wymogi efektywności i gospodarności.

Wykonywanie zadań publicznych przez jednostki samorządu terytorialnego stanowi jeden $\mathrm{z}$ elementów koniecznych do wyodrębnienia ich struktury $^{12}$. Podział zadań pomiędzy poszczególne szczeble samorządu powinien odpowiadać konstrukcji ustrojowej samorządu oraz argumentom racjonalności i skuteczności wiążącym się z identyfikacją potrzeb mieszkańców wspólnot samorządowych oraz jak najbardziej efektywnym sposobem ich zaspokojenia. Umieszczenie określonych kategorii zadań na odpowiednim szczeblu samorządu terytorialnego powinno być zatem wynikiem spełnienia powyższych przesłanek.

Podział zadań i kompetencji pomiędzy szczeble samorządu terytorialnego został określony w sposób ogólny w Konstytucji Rzeczypospolitej Polskiej $^{13}$ z 1997 r., a także w ustawach ustrojowych. Ustawy ustrojowe wskazują ogólne kierunki rozwiązań, które są uszczegóławiane w ustawach prawa materialnego ${ }^{14}$. Zakres zadań samorządu zależy od wydolności jednostki samorządowej oraz zamierzonego przez ustawodawcę stopnia jej samodzielności ${ }^{15}$, a także od tego czy ustawodawca nie zdecyduje się obarczyć gminy, powiatu czy województwa wykonywaniem zadań

11 Europejska Karta Samorządu Lokalnego, sporządzona w Strasburgu dnia 15 października 1985 r., Dz. U. z 1994 r. Nr 124, poz. 607 (dalej: EKSL).

12 Zob. I. Niżnik-Dobosz, Natura zadań samorzadu terytorialnego, [w:] M. Stec, S. Płażek (red.), Charakter i konstrukcja zadań samorzadu terytorialnego, Warszawa 2017, s. 237.

13 Konstytucja Rzeczypospolitej Polskiej z dnia 2 kwietnia 1997 r., Dz. U. z 1997 r. Nr 78, poz. 483 z późn. zm.

14 Zob. H. Izdebski, Samorząd terytorialny. Podstawy ustroju i działalności, Warszawa 2014, s. 179.

15 Zob. A. Wiktorowska, Samorzad terytorialny, s. 284. 
zleconych z zakresu administracji rządowej, obok wykonywania przez nie zadań własnych. Realizacja obu kategorii zadań staje się wówczas obligatoryjna. Nadużywanie tego rozwiązania rodzi niepokój o przeciążenie zadaniowe jednostek i skuteczność wykonywania zadań własnych, do których te jednostki zostały powołane. Natomiast z punktu widzenia wykonywania kompetencji powiązanych z przydzielonymi do konkretnej jednostki zadaniami, powinny być one rozdzielone wyraźnie pomiędzy organy państwa i organy samorządowe, zdecentralizowane. Gwarantuje to skuteczne działania organów i eliminuje paraliż kompetencyjny, który powstanie w przypadku niewłaściwego podziału kompetencji. Podział zadań i kompetencji jest więc ściśle ze sobą połączony. Ustawodawca powinien - łącząc zadania i kompetencje oraz przyporządkowując je do właściwego organu - uwzględniać porządek konstytucyjny, porządek normatywny, a także inne kryteria, w tym skuteczność i efektywność wykonywania zadań i realizowania kompetencji.

Na jednostki samorządowe nałożony został obowiązek wykonywania zadań własnych. Są to zadania służące zaspokajaniu zbiorowych potrzeb członków wspólnoty samorządowej. Określenie „zaspokajanie” jest związane z działaniami, które są skuteczne dla mieszkańców wspólnoty ${ }^{16}$. W art. 1 ustawy o gospodarce komunalnej ${ }^{17} \mathrm{z}$ dnia 20 grudnia 1996 r., określającej zasady i formy gospodarki komunalnej jednostek samorządu terytorialnego, ustawodawca wskazuje, że wśród zadań własnych, wykonywanych w celu zaspokojenia zbiorowych potrzeb wspólnoty samorządowej znajdują się zadania użyteczności publicznej, których celem jest bieżące i nieprzerwane zaspokajanie zbiorowych potrzeb ludności w drodze świadczenia usług powszechnie dostępnych. Ustawodawca dostarcza wskazówki interpretacyjnej dotyczącej skuteczności odnośnie do części wykonywanych zadań. W przypadku zadań użyteczności publicznej skuteczność będzie osiągana, jeśli zostaną spełnione dwie przesłanki: pierwsza dotyczy działania bieżącego, czyli związanego z zaspokajaniem potrzeb w momencie, w którym one powstają - bez zbędnej zwłoki, opóźnienia; druga przesłanka związana jest z działaniem ciągłym, trwającym stale. Można więc skonstatować, że te dwie przesłanki służą ocenie skuteczności działania mieszczącego się w grupie zadań użyteczności

16 Zob. E. Ura, Prawo administracyjne, Warszawa 2015, s. 195.

17 Ustawa z dnia 20 grudnia 1996 r. o gospodarce komunalnej, tekst jednolity: Dz. U. z 2019 r. poz. 712 z późn. zm. 
publicznej. W przypadku pozostałych zadań własnych należy - na podstawie przepisów prawa - identyfikować cel związany z nimi, by następnie dokonać oceny, czy i w jakim stopniu został on osiągnięty.

Jednostki samorządowe powinny więc koncentrować się nie na samym procesie świadczenia usług, ale na osiąganych dzięki niemu efektywnych ekonomicznie i społecznie wynikach. Takie podejście zakłada ukierunkowanie się na działalność planową, strategiczną ${ }^{18}$.

Ułatwieniu oceny realizacji danego celu służą dokumenty tworzone przez organy samorządowe. Każda z jednostek samorządowych ma obowiązek realizacji podejmowanych uchwał, planów, polityk, programów, strategii, w których przewiduje jakie działania i w jakim okresie czasu zostaną podjęte oraz cele, które mają one urzeczywistniać. Ich weryfikacja pozwoli na ocenę skuteczności wskazanych w nich działań. Przykładem narzędzia weryfikacyjnego jest obowiązek ustawowy nałożony na wójta, zarząd powiatu, zarząd województwa, aby co roku do dnia 31 maja przedstawiał organowi stanowiącemu raport o stanie jednostki samorządowej. Treścią raportu jest podsumowanie działalności organu wykonawczego w roku poprzednim, w szczególności z realizacji polityk, programów i strategii, uchwał organu stanowiącego i budżetu obywatelskiego. Po zakończeniu debaty nad raportem o stanie jednostki samorządowej organ stanowiący przeprowadza głosowanie nad udzieleniem organowi wykonawczemu wotum zaufania. W przypadku podjęcia uchwały o nieudzieleniu wotum zaufania $w$ dwóch kolejnych latach rada gminy może podjąć uchwałę o przeprowadzeniu referendum w sprawie odwołania wójta ${ }^{19}$, a w powiecie i województwie jest to równoznaczne ze złożeniem wniosku

18 Jest to założenie właściwe dla koncepcji nowego zarządzania publicznego, która kładzie nacisk na wykorzystanie w sektorze publicznym metod zarządzania stosowanych w sektorze prywatnym. Koncepcja ta zakłada: zmianę orientacji zarządzania organizacjami publicznymi z nakładów i procedur na osiąganie wyników, oparcie się na podejściu strategicznym, rozdział ról nabywcy od dostarczyciela usług, tworzenie stosunków rynkowych i organizowanie konkurencji w procesie świadczenia usług, zorientowanie działań na klienta, uelastycznienie warunków zatrudnienia, pracy i płacy, depolityzację zarządzania poprzez rozdział polityki publicznej od zarządzania operacyjnego, wprowadzenie mierników i standardów usług. Zob. A. Zalewski, Reformy sektora publicznego w duchu nowego zarządzania publicznego, [w:] A. Zalewski (red.), Nowe zarządzanie publiczne w polskim samorzadzie terytorialnym, Warszawa 2007, s. 28-29, 43.

19 Art. 28aa ustawy z dnia 8 marca 1990 r. o samorządzie gminnym, tekst jednolity: Dz. U. z 2019 r. poz. 506 z późn. zm. (dalej: u.s.g.). 
o odwołanie zarządu ${ }^{20}$. Kolejnym narzędziem jest udzielenie wójtowi, zarządowi powiatu, zarządowi województwa absolutorium z wykonania budżetu przez radę gminy, radę powiatu, sejmik województwa ${ }^{21}$. Rada gminy, może także podjąć uchwałę o przeprowadzeniu referendum w sprawie odwołania wójta z przyczyny innej niż nieudzielenie wójtowi absolutorium lub nieudzielenie wójtowi wotum zaufania ${ }^{22}$. W powiecie oraz $\mathrm{w}$ województwie zarząd powiatu oraz zarząd województwa może zostać odwołany z innej przyczyny niż nieudzielenie absolutorium. Dodatkowo rada powiatu może odwołać starostę, a sejmik województwa marszałka województwa, z innej przyczyny niż nieudzielenie absolutorium lub nieudzielenie wotum zaufania zarządowi $\mathrm{i}^{23}$. Instrumentem prawnym, wskazanym w ustawach samorządowych wpływającym na skuteczność, a dokładniej na jej przywrócenie, jest również środek nadzorczy - zarząd komisaryczny. Zostanie on omówiony poniżej w aspekcie konsekwencji braku skuteczności działania organów samorządowych.

Osiąganiu skuteczności mają służyć prawne formy działania wskazane w ustawach samorządowych, które ustawodawca różnicuje w zależności od stopnia podziału terytorialnego. Należą do nich: tworzenie jednostek pomocniczych w gminie ${ }^{24}$, tworzenie jednostek organizacyjnych, zawieranie umów $\mathrm{z}$ innymi podmiotami ${ }^{25}$, w tym $\mathrm{z}$ organizacjami pozarządowymi w celu wykonywania zadań publicznych ${ }^{26}$, współdziałanie między jednostkami samorządu terytorialnego w celu wykonywania zadań publicznych $\mathrm{w}$ formie porozumieńn ${ }^{27}$ i związków komunalnych ${ }^{28}$, udzielanie pomocy, w tym pomocy finansowej przez gminy, powiaty, województwa, związki międzygminne, związki i stowarzyszenia powiatów oraz stowarzyszenia jednostek samorządu terytorialnego, sobie wzajemnie bądź

20 Art. 30a ustawy z dnia 5 czerwca 1998 r. o samorządzie powiatowym, tekst jednolity: Dz. U. z 2019 r. poz. 511 z późn. zm. (dalej: u.s.p.); art. 34a ustawy z dnia 5 czerwca 1998 r. o samorządzie województwa, tekst jednolity: Dz. U. z 2019 r. poz. 512 z późn. zm. (dalej: u.s.w.).

${ }^{21}$ Art. 28a u.s.g.; art. 30 u.s.p.; art. 34 u.s.w.

22 Art. $28 b$ u.s.g.

23 Art. 31 u.s.p.; art. 37 u.s.w.

24 Art. 5 u.s.g.

25 Art. 6 ust. 1 u.s.p.; art. 8 ust. 1 u.s.w.

26 Art. 9 ust. 1 u.s.g.

27 Art. 8 ust. 2a u.s.g., art. 74 u.s.g.; art. 5 ust. 2 u.s.p., art. 73 u.s.p.; art. 8 ust. 2 u.s.w.

28 Art. 64-73b u.s.g.; art. 65-72c u.s.p. 
innym jednostkom samorządu terytorialnego ${ }^{29}$, zapewnienie wspólnej obsługi, w szczególności administracyjnej, finansowej i organizacyjnej dla wskazanych jednostek organizacyjnych ${ }^{30}$. Są to rozwiązania, które mają za zadanie zwiększenie elastyczności i samodzielności działania jednostek samorządu terytorialnego oraz przyczynienie się do realizacji określonych celów ${ }^{31}$.

Na osiąganie skuteczności działania wpływają także relacje prawne pomiędzy organami jednostek samorządowych. Skoro przymiotem jednostek samorządu terytorialnego jest, zagwarantowana konstytucyjne i ustawowo, samodzielność - jej konsekwencją jest wykonywanie władzy publicznej poprzez organy samorządowe na określonym terytorium. "Organy samorządu terytorialnego są organami władzy publicznej i wykonując zadania publiczne powinny kierować się prawem i interesem publicznym", który wyraża się m.in. w skutecznym wykonywaniu zadań publicznych ${ }^{32}$. Skuteczność w działaniu organów samorządowych będzie więc dotyczyła dwóch aspektów: aspekt pierwszy obejmuje współpracę organów stanowiących i wykonawczych; natomiast aspekt drugi koncentruje się na realizacji ustawowego obowiązku związanego z wykonywaniem zadań publicznych. Realizacja aspektu dotyczącego współpracy organów wiąże się z podziałem ról organów oraz rozdzieleniem zakresu spraw przez nie wykonywanych, a z drugiej strony wzajemnym uzupełnianiem się $\mathrm{w}$ działaniu. $\mathrm{W}$ gminie wójt wykonuje uchwały rady gminy i zadania gminy określone przepisami prawa. W realizacji zadań własnych gminy wójt podlega wyłącznie radzie gminy ${ }^{33}$. Rada gminy stanowi także o kierunkach działania wójta ${ }^{34}$.

Zatem, gdy rada nie funkcjonuje, niemożliwe jest wykonywanie przez gminę ustawowych zadań, m.in. przez podejmowanie uchwał w sprawach istotnych dla gminy. W takiej sytuacji również wójt gminy - jako jej organ

29 Art. 10 u.s.g.; art. 7a u.s.p.; art. 8a u.s.w.

30 Art. 10a u.s.g.; art. 6a u.s.p.; art. 8c u.s.w.

31 Zob. I. Ścieszka, Wspólna obstuga, jednostki obstugiwane, [w:] S. Gajewski, A. Jakubowski (red.), Ustawy samorządowe. Komentarz, Warszawa 2018, s. 169.

32 Wyrok NSA z dnia 5 marca 2013 r., II OSK 135/13; zob. J. Jagoda, Tryb wyborów organów wykonawczych a ich relacje z organami stanowiacymi jednostek samorzadu terytorialnego, [w:] M. Stec, K. Małysa-Sulińska (red.), Pozycja ustrojowa organów wykonawczych jednostek samorzadu terytorialnego, Warszawa 2014, s. 108.

33 Art. 30 ust. 3 u.s.g.

34 Art. 18 ust. 2 pkt 2 u.s.g. 
wykonawczy nie jest w stanie w pełni wykonywać powyższych ustawowych obowiązków. [...] Bez współdziałania obu tych organów nie można mówić o skutecznym funkcjonowaniu gminy. Rada gminy jest bowiem nie tylko organem stanowiącym, ale także kontrolnym w stosunku do organu wykonawczego, jakim jest wójt. Działania wójta, jakkolwiek samodzielne, są w znacznej części wyznaczone przez rozstrzygnięcia rady gminy (stanowią pochodną uchwał rady gminy) $)^{35}$.

W powiecie oraz w województwie organ wykonawczy - zarząd - jest wybierany przez organ stanowiący, który, podobnie jak w gminie, działa w ramach swych ustawowych kompetencji, ale w znacznej części działania zarządu podejmowane są w ramach upoważnień wskazanych w uchwałach organu stanowiącego. Niedziałanie lub nieprawidłowe funkcjonowanie organów lub jednego z organów powoduje paraliż działania i wpływa bezpośrednio na jego skuteczność.

Skuteczność wykonywania zadań jest jednoznacznie powiązana z posiadaniem na ich wykonanie odpowiednich środków $w^{36}$. Do instrumentów finansowych mogących wpływać na skuteczność działania można zaliczyć budżet zadaniowy i programy naprawcze. Istotą budżetu zadaniowego jest metodologia przygotowania i wykonywania planu finansowego, gdzie wydatkowanie środków pieniężnych jest ściśle powiązane z osiąganymi wynikami ${ }^{37}$. Opiera się na zasadach przejrzystości, skuteczności i wieloletniości. Określenie celów i mierników pozwala na uzyskanie jak najlepszych efektów z poczynionych nakładów ${ }^{38}$. Kluczowym elementem tego budżetu jest określenie celów strategicznych i zadań oraz oczekiwanych wyników o charakterze społecznym i ekonomicznym ${ }^{39}$. Natomiast program naprawczy służy zabezpieczeniu wykonywania zadań publicznych w razie braku możliwości uchwalenia wieloletniej prognozy finansowej lub budżetu jednostki samorządu terytorialnego - zgodnie z zasadami określonymi w ustawie o finansach publicznych - oraz w razie zagrożenia

35 Wyrok NSA z dnia 24 listopada 2009 r., II OSK 1786/09, CBOSA.

36 Zob. wyrok NSA z dnia 26 października 2016 r., II OSK 2347/16.

37 Zob. E. Juchniewicz, Budżet zadaniowy, [w:] A. Drwiłło (red.), Podstawy finansów i prawa finansowego, Warszawa 2018, s. 413.

38 Zob. K. Kopyściańska, Budżet zadaniowy, [w:] W. Miemiec (red.), Prawo finansów publicznych z kazusami i pytaniami, Warszawa 2018, s. 128.

39 Zob. T. Lubińska (red.), Budżet zadaniowy w Polsce. Reorientacja z wydatkowania na zarządzanie pieniędzmi publicznymi, Warszawa 2007; E. Kornberger-Sokołowska, M. Bitner, Prawo finansów samorzadowych, Warszawa 2018, s. 66-68. 
realizacji zadań publicznych przez jednostkę samorządu terytorialnego. Organ stanowiący jednostki samorządu terytorialnego uchwala program postępowania naprawczego na okres nieprzekraczający trzech kolejnych lat budżetowych ${ }^{40}$. Realizacja programu naprawczego ma umożliwić jednostce samorządowej realizację zadań w trakcie trwania programu oraz po jego zakończeniu ${ }^{41}$. Czynnik finansowo-ekonomiczny, choć istotny i częstokroć bezpośrednio warunkujący skuteczność realizacji zadań publicznych, nie może jednak całkowicie przesłaniać innych aspektów ich wykonywania ${ }^{42}$.

\section{Prakseologiczne uwarunkowania skuteczności}

Na skuteczne wykonywanie zadań publicznych wpływają także warunki związane z organizacją struktury, w ramach której są one realizowane. Organizacja struktury związana jest z realizacją postulatów zasady decentralizacji oraz przyznaniem jednostkom zdecentralizowanym kompetencji do jej doprecyzowania w ramach upoważnień ustawowych. Samodzielność organizacyjna została wyrażona w Europejskiej Karcie Samorządu Lokalnego i zakłada, że jeśli bardziej ogólne postanowienia ustawy nie stanowią inaczej, społeczności lokalne powinny móc samodzielnie ustalać swą wewnętrzną strukturę administracyjną, tworząc jednostki dostosowane do specyficznych potrzeb i umożliwiające skuteczne zarządzanie $^{43}$. Jest ona realizowana na podstawie upoważnień ustawowych w ramach formalizacji prawnej, która jest czynnikiem pozyskiwania skuteczności administracji i wyznacza granice organizacyjnej elastyczności. Dyrektywa legalności wpływa na podporządkowanie reguł organizacyjnych. Oznacza to, że w organizowaniu prawem administracji wybór reguł organizacji jest dokonywany w oparciu o kryterium legalności, dlatego że są one prawnie dopuszczalne. Jest to prawna skuteczność. W konsekwencji, kategoria technicznej sprawności, związana z racjonalizacją działania

40 Art. 240a ustawy z dnia 27 sierpnia 2009 r. o finansach publicznych, tekst jednolity:

Dz. U. z 2019 r. poz. 869 z późn. zm.

41 Zob. P. Sołtyk, M. Dębowska-Sołtyk, Finanse samorzadowe, Warszawa 2016, s. 118.

${ }^{42}$ Zob. wyrok TK z dnia 9 kwietnia 2002 r., K 21/01, OTK ZU 2002, nr 2A, poz. 17.

43 Art. 6 ust. 1 EKSL. 
administracji, może być jedynie punktem wyjścia do tworzenia pojęcia skuteczności administracji ${ }^{44}$. Przejawami prakseologicznej skuteczności uregulowanymi w ustawach samorządowych są przepisy dotyczące organizacji pracy organów stanowiących przez ich przewodniczących, $w$ efekcie czego praca rady czy sejmiku powinna być zorganizowana w sposób, by skutecznie i terminowo realizować przez organy samorządowe obowiązki i zadania publiczne nałożone na nie ustawą ${ }^{45}$. Wśród rozwiązań o charakterze prakseologicznym przyczyniających się do osiągania skuteczności można także wskazać: wybór formy prowadzenia gospodarki gminnej, zapewnienie wspólnej obsługi organizacyjnej dla wskazanych jednostek organizacyjnych, gospodarowanie mieniem komunalnym z uwzględnieniem szczególnej staranności, określanie organizacji wewnętrznej oraz trybu pracy organów jednostki samorządowej, określanie organizacji i zasad funkcjonowania urzędu gminy, starostwa powiatowego, urzędu marszałkowskiego w regulaminie organizacyjnym, określanie organizacji jednostki pomocniczej, wspieranie idei samorządu terytorialnego oraz obrony wspólnych interesów w formie stowarzyszenia jednostek samorządu terytorialnego.

Organizowanie aparatu administracyjnego powinno mieć ciągły charakter, opierający się na sprawdzaniu skuteczności organizacji i wprowadzaniu zmian w celu jej utrzymania lub zwiększania. Organizowanie powinno również uwzględniać ocenę jej struktury. Jest to szczególnie istotne w sytuacji rozrostu organizacji i sprawnego funkcjonowania dostosowanego do istniejących potrzeb ${ }^{46}$. Właściwe przyporządkowanie zadań i kompetencji, wykonywanie ich przez odpowiednie jednostki samorządu terytorialnego jest, obok kształtowania struktur, głównym czynnikiem skuteczności. Wspólnie stanowią one o organizacji administracji ${ }^{47}$.

44 Zob. J. Łukasiewicz, Prawne uwarunkowania skuteczności działań administracji państwowej, Lublin 1990, s. 7-8.

45 Zob. wyrok Wojewódzkiego Sądu Administracyjnego (WSA) w Białymstoku z dnia 23 sierpnia 2007 r., II SA/Bk 461/07, CBOSA; zob. J. Jagoda, Komentarz do art. 2, teza 14, [w:] B. Dolnicki (red.), Ustawa o samorzadzie gminnym. Komentarz, Warszawa 2016, s. 55-56.

46 Zob.S. Cieślak, Praktyka organizowania administracji publicznej, Warszawa 2004, s. 27, 119-120.

47 Zob. J. Łukasiewicz, Prawne uwarunkowania skuteczności..., s. 91. 


\section{Konsekwencje braku skuteczności działania organów samorządowych}

Prawo, kształtując struktury zdecentralizowane, wprowadza określone mechanizmy kontrolne oraz weryfikacyjne, których celem jest eliminacja z obiegu prawnego działań podmiotów zdecentralizowanych wykraczających poza obszar ich prawnie określonych zadań i kompetencji. Zadaniem instytucji nadzoru jest utrzymanie działalności zdecentralizowanego podmiotu - korporacji terytorialnej - w granicach prawa ${ }^{48}$.

Konsekwencją prawną nierokującego nadziei na szybką poprawę i przedłużającego się braku skuteczności w wykonywaniu zadań publicznych przez organy gminy, powiatu, województwa jest zastosowanie środka nadzorczego - zarządu komisarycznego.

Przez brak skuteczności w wykonywaniu zadań publicznych rozumieć należy niewywiązywanie się przez organy jednostek samorządu terytorialnego z obowiązków wynikających z przepisów ustawowych, zredagowanych w taki sposób, który pozwala na wyprowadzenie z nich pożądanego rezultatu określonych działań ${ }^{49}$.

Zarząd komisaryczny ustanawiany jest na okres do dwóch lat, nie dłużej jednak niż do wyboru rady gminy oraz wójta na kolejną kadencję, a w przypadku powiatu i województwa nie dłużej niż do wyboru zarządu przez radę/sejmik kolejnej kadencji. O ile Prezes Rady Ministrów, na wniosek ministra właściwego do spraw administracji publicznej, może zawiesić organy, to podjęcie decyzji o zawieszeniu skutkuje obowiązkiem ustanowienia zarządu komisarycznego. Jest to działanie nierozłączne nie można zawiesić organów bez ustanowienia zarządu komisarycznego. Istotę tego środka nadzorczego stanowi powołanie komisarza, a zawieszenie organów jest tylko warunkiem koniecznym dla podjęcia tej decyzji50.

Wprowadzenie zarządu komisarycznego jest uznaniowym aktem nadzoru stosowanym w oparciu o kryterium legalności, które wynika

48 Wyrok NSA z dnia 26 października 2016 r., II OSK 2347/16.

49 Wyrok NSA z dnia 24 listopada 2009 r., II OSK 1786/09; zob. K. Wojciechowska, Zawieszenie organów. Zarząd komisaryczny, [w:] S. Gajewski, A. Jakubowski (red.), Ustawy samorzadowe. Komentarz, Warszawa 2018, s. 738.

50 Zob. wyrok NSA z dnia 26 października 2016 r., II OSK 2347/16. 
ze wskazanych $\mathrm{w}$ rozstrzygnięciu nadzorczym naruszonych przepisów ustaw. Organy władzy publicznej, jakimi są organy jednostek samorządu terytorialnego, działają na podstawie i w granicach prawa i wykonywanie zadań publicznych jest ich obowiązkiem. Niewykonywanie ustawowo przekazanych jednostce samorządu terytorialnego zadań oznacza naruszenie podstawowych, ustawowych obowiązków władzy samorządowej. Przedłużający się, bez nadziei na szybką poprawę, brak skuteczności w wykonywaniu ustawowo przekazanych zadań publicznych zawsze wiąże się więc $\mathrm{z}$ naruszaniem Konstytucji RP i ustaw ${ }^{51}$.

Organy samorządu terytorialnego są organami władzy publicznej i wykonując zadania publiczne powinny kierować się prawem i interesem publicznym. Interes publiczny wyraża się m.in. w skutecznym wykonywaniu zadań publicznych. Dostrzegając naruszenia prawa i inne okoliczności potwierdzające "przedłużający się i nie rokujący nadziei na szybką poprawę brak skuteczności w wykonywaniu zadań publicznych" organ nadzoru powinien podjąć działania zabezpieczające wykonywanie zadań publicznych. Ocena braku skuteczności obejmuje wszelkie działania organów gminy, „"w tym te, które związane są z obrotem majątkiem gminy i dokonywane są z naruszeniem przepisów regulujących gospodarowanie majątkiem publicznym. Także mnożenie zobowiązań cywilnoprawnych lub ich niewykonywanie, jeśli prowadzą do skutków finansowych przyczyniających się do braku skuteczności działania, podlegać może ocenie przez organ nadzoru" 52 .

Specyfika zarządu komisarycznego wyraża się w tym, że dla określenia przesłanki jego zastosowania ustawodawca użył zwrotów ocennych (pojęć niedookreślonych) takich jak: „brak skuteczności”, „przedłużający się", "nierokujący nadziei na szybką poprawę", których dekodowanie w konkretnym przypadku wymaga określonych zabiegów interpretacyjnych mogących rodzić określone trudności. Niewystarczające jest dokonanie abstrakcyjnej interpretacji zapisanego w tekście aktu prawnego wyrażenia wieloznacznego z punktu widzenia dostępnych metod wykładni przepisu prawa, ponieważ przedmiotem czynności interpretacyjnych pozostaje w tym przypadku nierozerwalnie sfera faktu i sfera prawa. Przy wyjaśnianiu wskazanych zwrotów ocennych stwierdzenie faktów "zlewa" się z ich ewaluacją, polegającą na ocenie poddanych analizie stanów

51 Zob. wyrok NSA z dnia 24 listopada 2009 r., II OSK 1786/09.

52 Wyrok NSA z dnia 5 marca 2013 r., II OSK 135/13. 
rzeczy, zdarzeń lub procesów z punktu widzenia kryteriów przyjętych przez podmiot oceniający ${ }^{53}$.

Sformułowany w normie postępowania wzór zachowania uzależniony jest od dokonania wyboru wartościującego w stosunku do ustalonych w sprawie okoliczności faktycznych. Zwrot ocenny, będąc zwrotem o charakterze normatywnym, ma oczywiście obiektywną i poznawalną treść, niemniej jednak - $\mathrm{z}$ uwagi na pozostawanie $\mathrm{w}$ nierozłącznym związku z całokształtem okoliczności faktycznych konkretnej sprawy - nie poddaje się abstrakcyjnemu zdefiniowaniu. Zatem każda ocena dokonywana przez organ stosujący prawo, w przypadku stosowania takiego zwrotu, musi być oceną jednostkową i sytuacyjną. Zwroty ocenne „wymagają systematycznego dookreślania, tzn. uzyskują treściowe kontury dopiero w trakcie ustalania treści poszczególnych interesów indywidualnych, kształtowanych na bazie prawa administracyjnego materialnego" ${ }^{54}$.

Dodatkowo, ustawa nie wymaga, by oceniając skuteczność wykonywania zadań publicznych, rozważać tę przesłankę odrębnie w stosunku do organu stanowiącego i odrębnie w stosunku do organu wykonawczego oraz odstępować od zastosowania środka nadzoru określonego w powołanym przepisie $\mathrm{w}$ sytuacji, gdy niedziałanie np. rady $\mathrm{w}$ większym stopniu niż działanie wójta przyczyniło się do braku skuteczności w wykonywaniu zadań publicznych. Zatem niezależnie od tego, w jakim stopniu jeden z organów gminy przyczynił się do powstania braku skuteczności, z uwagi na ich wzajemne funkcjonalne powiązanie, skutki zastosowania tego środka nadzoru obejmują oba organy ${ }^{55}$.

\section{Zakończenie}

Administracja działa $\mathrm{w}$ otoczeniu, które podlega przeobrażeniom. Dotyczy to zarówno zmian w ustawodawstwie, czy też zmian w zakresie wykonywanych zadań, do których dochodzi w wyniku zlecenia zadań

53 Zob. L. Leszczyński, Stosowanie generalnych klauzul odsyłających, Kraków 2001, s. 154.

${ }_{54}$ M. Zdyb, Interes jednostki w sferze luzów normatywnych (pojęcia nieostre), "Annales Universitatis Mariae Curie-Skłodowska" Sectio G Ius 1991, nr 1, s. 354.

55 Zob. wyrok WSA w Warszawie z dnia 10 października 2012 r., II SA/Wa 1329/12, CBOSA. 
administracji rządowej. W związku z powyższym zdolność jednostki samorządowej do osiągania swoich celów ustawowych związanych z obowiązkiem realizacji zadań własnych może także się zmieniać.

Wykonując zadania publiczne organy samorządowe zobligowane są do podejmowania działań skutecznych, czyli realizujących lub zbliżających się do realizacji powiązanych z nimi celów. Jednakże w związku z tym, że pojęcie „skuteczność” ma charakter ocenny - co wiąże się z trudnością jego zdefiniowania - oraz podlega stopniowaniu, stopień komplikacji będzie także dotyczył oceny, czy podjęte działanie było skuteczne i w jakim stopniu cel został osiągnięty. Dlatego samo zaplanowanie i podjęcie działania jest niewystarczające, lecz powinno zawierać w sobie element celowości, do którego konkretne czynności będą je przybliżać. Cel ten powinien być każdorazowo nazwany i scharakteryzowany, co umożliwi weryfikację działania pod kątem jego skuteczności.

Ustawodawca nakłada na organy samorządowe obowiązek podejmowania działań zaspokajających potrzeby mieszkańców wspólnot samorządowych. Skala potrzeb jest zależna od uwarunkowań konkretnej jednostki samorządowej, dlatego ocena skuteczności będzie dokonywana każdorazowo w odniesieniu do takiej jednostki. Nie jest więc możliwe prawne określenie zestawu mierników badających stopień osiągania skuteczności, ze względu na obiektywne przesłanki różnicujące jednostki samorządowe: układ osadniczy, przestrzenny, więzi społeczne, gospodarcze i kulturowe.

Wykonywanie zadań publicznych przez jednostki samorządu terytorialnego stanowi jeden z elementów koniecznych do wyodrębnienia ich struktury. Podział zadań pomiędzy poszczególne szczeble samorządu powinien odpowiadać konstrukcji ustrojowej samorządu oraz argumentom racjonalności i skuteczności wiążącym się z identyfikacją potrzeb mieszkańców wspólnot samorządowych oraz jak najbardziej efektywnym sposobem ich zaspokojenia. Umieszczenie określonych kategorii zadań na odpowiednim szczeblu samorządu terytorialnego powinno być wynikiem spełnienia powyższych przesłanek. Aby postulat skuteczności w wykonywaniu zadań publicznych mógł być urzeczywistniony, nie można pominąć potencjału sił i środków, którymi dysponuje jednostka samorządowa. Dzięki określonym w ustawach samorządowych rozwiązaniom - obejmującym sposób wykonywania zadań publicznych, strukturę, w ramach której są one wykonywane, a także relacje prawne pomiędzy organem stanowiącym i wykonawczym - skuteczność staje się determinantą działań 
organów jednostek samorządu terytorialnego w aspekcie zadaniowym, funkcjonalnym i organizacyjnym.

Ocena skuteczności działania w przypadku stosowania środka nadzorczego w postaci ustanowienia zarządu komisarycznego jest dokonywana w oparciu o kryterium legalności, co oznacza, że ocenie podlegać będzie zarówno sytuacja, gdy organ

funkcjonuje i skutecznie wykonuje swoje zadania, ale jednocześnie, podejmując działania niemieszczące się w zakresie jego zadań i kompetencji lub w nieprzewidzianych przez prawo formach, narusza Konstytucję i ustawy oraz sytuacje, gdy ustawowych zadań po prostu nie wykonuje bądź wykonuje je nieskutecznie, a taki stan się przedłuża, czym także narusza Konstytucję i ustawy ${ }^{56}$.

Jednakże „skuteczność w wykonywaniu zadań publicznych” powinna być także oceniana w kontekście osiągania celów powiązanych z zadaniami wykonywanymi na rzecz społeczności lokalnej. Ocenie podlegać będzie wówczas stopień realizacji zamierzeń wskazanych w dokumentach o charakterze strategicznym. Jeżeli więc jednostka samorządowa zobowiąże się do realizacji działań, które mają zakończyć się wskazanym efektem, a celu tego nie uda się zrealizować, sytuacja ta nie będzie stanowić podstawy do ustanowienia zarządu komisarycznego. Konsekwencje będą wówczas wiązały się z nieudzieleniem poparcia dla obecnych władz samorządowych $w$ kolejnych wyborach, ewentualnie z możliwością złożenia wniosku przez mieszkańców o przeprowadzenie referendum w sprawie odwołania organu pochodzącego z wyborów bezpośrednich.

Skuteczność działania może być więc oceniana z punktu widzenia jego zgodności z prawem oraz z punktu widzenia prakseologicznego. Może być oceniana przez organy samorządowe, mieszkańców wspólnot, wreszcie przez organ nadzorczy. W zależności od tego, jakie instrumenty prawne będą stosowane do oceny skuteczności oraz przez jaki podmiot skuteczność lub jej brak będzie oceniana konsekwencje dla podejmowanych przez organ działań będą różniły się stopniem ingerencji. Najgłębszą będzie zastosowanie środka nadzorczego w postaci zarządu komisarycznego. Jednakże w przypadku podjęcia działania legalnego przez organy, ale nie przynoszącego realizacji danego celu, np. w przypadku niezrealizowanej obietnicy wyborczej, konsekwencja związana z nieskutecznym

56 Wyrok WSA w Warszawie z dnia 16 maja 2016 r., II SA/Wa 482/16, CBOSA. 
działaniem może nie pojawić się w ogóle, jeżeli mieszkańcy wspólnoty w kolejnych wyborach samorządowych dokonają podobnego wyboru.

Słowa kluczowe: skuteczność, samorząd terytorialny, zadania publiczne

\section{Bibliografia}

\section{Źródła}

\section{Akty prawne}

Konstytucja Rzeczypospolitej Polskiej z dnia 2 kwietnia 1997 r., Dz. U. z 1997 r. Nr 78, poz. 483 z późn. zm.

Ustawa z dnia 8 marca 1990 r. o samorządzie gminnym, tekst jednolity: Dz. U. z 2019 r. poz. 506 z późn. zm.

Ustawa z dnia 20 grudnia 1996 r. o gospodarce komunalnej, tekst jednolity: Dz. U. z 2019 r. poz. 712 z późn. zm.

Ustawa z dnia 5 czerwca 1998 r. o samorządzie powiatowym, tekst jednolity: Dz. U. z 2019 r. poz. 511 z późn. zm.

Ustawa z dnia 5 czerwca 1998 r. o samorządzie województwa, tekst jednolity: Dz. U. z 2019 r. poz. 512 z późn. zm.

Ustawa z dnia 27 sierpnia 2009 r. o finansach publicznych, tekst jednolity: Dz. U. z 2019 r. poz. 869 z późn. zm.

Europejska Karta Samorządu Lokalnego, sporządzona w Strasburgu dnia 15 października 1985 r., Dz. U. z 1994 r. Nr 124, poz. 607.

\section{Orzecznictwo}

Wyrok Trybunału Konstytucyjnego z dnia 9 kwietnia 2002 r., K 21/01, OTK ZU 2002, nr 2A, poz. 17.

Wyrok Trybunału Konstytucyjnego z dnia 18 lutego 2003 r., K 24/02, OTK ZU 2003, nr 2A, poz. 11.

Wyrok Naczelnego Sądu Administracyjnego z dnia 24 listopada 2009 r., II OSK 1786/09, Centralna Baza Orzeczeń Sądów Administracyjnych (CBOSA).

Wyrok Naczelnego Sądu Administracyjnego z dnia 5 marca 2013 r., II OSK 135/13, CBOSA.

Wyrok Naczelnego Sądu Administracyjnego z dnia 26 października 2016 r., II OSK 2347/16, CBOSA.

Wyrok Wojewódzkiego Sądu Administracyjnego w Białymstoku z dnia 23 sierpnia 2007 r., II SA/Bk 461/07, CBOSA. 
Wyrok Wojewódzkiego Sądu Administracyjnego w Warszawie z dnia 10 października 2012 r., II SA/Wa 1329/12, CBOSA.

Wyrok Wojewódzkiego Sądu Administracyjnego w Warszawie z dnia 16 maja 2016 r., II SA/Wa 482/16, CBOSA.

\section{Literatura}

Cieślak S., Praktyka organizowania administracji publicznej, Warszawa 2004.

Dawidowicz W., Zagadnienia ustroju administracji państwowej w Polsce, Warszawa 1970.

Górski M., Zasada subsydiarności a zakres kompetencji w ochronie środowiska, [w:] E. Ura (red.), Granice samodzielności wspólnot samorządowych. Międzynarodowa Konferencja Naukowa, Baranów Sandomierski 22-25 maja 2005 r., Rzeszów 2005.

Izdebski H., Samorząd terytorialny. Podstawy ustroju i działalności, Warszawa 2014. Jagoda J., Komentarz do art. 2, teza 14, [w:] B. Dolnicki (red.), Ustawa o samorzadzie gminnym. Komentarz, Warszawa 2016.

Jagoda J., Tryb wyborów organów wykonawczych a ich relacje z organami stanowiącymi jednostek samorządu terytorialnego, [w:] M. Stec, K. Małysa-Sulińska (red.), Pozycja ustrojowa organów wykonawczych jednostek samorządu terytorialnego, Warszawa 2014.

Jaworska-Dębska B., Zadania samorzadu terytorialnego, [w:] M. Stahl (red.), Prawo administracyjne. Pojęcia, instytucje, zasady w teorii i orzecznictwie, Warszawa 2019.

Juchniewicz E., Budżet zadaniowy, [w:] A. Drwiłło (red.), Podstawy finansów i prawa finansowego, Warszawa 2018.

Kopyściańska K., Budżet zadaniowy, [w:] W. Miemiec (red.), Prawo finansów publicznych z kazusami i pytaniami, Warszawa 2018.

Kornberger-Sokołowska E., M. Bitner, Prawo finansów samorządowych, Warszawa 2018.

Kotarbiński T., Traktat o dobrej robocie, Wrocław-Warszawa-Kraków-Gdańsk 1975.

Leszczyński L., Stosowanie generalnych klauzul odsyłających, Kraków 2001.

Lubińska T. (red.), Budżet zadaniowy w Polsce. Reorientacja z wydatkowania na zarzadzanie pieniędzmi publicznymi, Warszawa 2007.

Lubińska T. i in., Budżet zadaniowy w Polsce - istota, struktura, metodyka, [w:] T. Lublińska (red.), Nowe zarządzanie publiczne - skuteczność i efektywność. Budżet zadaniowy w Polsce, Warszawa 2009.

Łukasiewicz J., Prawne uwarunkowania skuteczności działań administracji państwowej, Lublin 1990.

Niżnik-Dobosz I., Natura zadań samorządu terytorialnego, [w:] M. Stec, S. Płażek (red.), Charakter i konstrukcja zadań samorzadu terytorialnego, Warszawa 2017.

Pszczołowski T., Celowość, skuteczność i efektywność, „Prakseologia” 1977, nr 3.

Sołtyk P., M. Dębowska-Sołtyk, Finanse samorządowe, Warszawa 2016. 
Sułkowski M., R. Wolniak, Przeglad stosowanych metod oceny skuteczności i efektywności organizacji zorientowanych na ciagłe doskonalenie, ,Zeszyty Naukowe Politechniki Śląskiej" Organizacja i Zarządzanie 2013, z. 67.

Szpor A., Państwo a subsydiarność jako zasada prawa w UE $i$ w Polsce, „Samorząd Terytorialny" 2001, $\mathrm{nr} 1 / 2$.

Ścieszka I., Wspólna obstuga, jednostki obstugiwane, [w:] S. Gajewski, A. Jakubowski (red.), Ustawy samorzadowe. Komentarz, Warszawa 2018.

Ura E., Prawo administracyjne, Warszawa 2015.

Wiktorowska A., Samorzad terytorialny, [w:] J. Jagielski, M. Wierzbowski (red.), Prawo administracyjne, Warszawa 2019.

Wojciechowska K., Zawieszenie organów. Zarząd komisaryczny, [w:] S. Gajewski, A. Jakubowski (red.), Ustawy samorzadowe. Komentarz, Warszawa 2018.

Zalewski A., Reformy sektora publicznego w duchu nowego zarzadzania publicznego,

[w:] A. Zalewski (red.), Nowe zarzadzanie publiczne w polskim samorzadzie terytorialnym, Warszawa 2007.

Zdyb M., Interes jednostki w sferze luzów normatywnych (pojęcia nieostre), „Annales Universitatis Mariae Curie-Skłodowska" Sectio G Ius 1991, nr 1.

\section{EFFECTIVENESS AS A DETERMINANT OF THE ACTIVITIES OF LOCAL GOVERNMENT BODIES}

\section{Summary}

A statutory obligation to perform public tasks has been imposed on local government units - their own tasks, the purpose of which is to satisfy the needs of local communities. Therefore, local government units are also obliged to undertake such actions and select such legal instruments as to make their implementation effective, i.e. to achieve the intended objectives or at least pursue them. The effectiveness of tasks performed by local and regional authorities is affected by the fact that they are carried out at the appropriate level by local and regional authorities, by the proper allocation of tasks and responsibilities in accordance with the principles of decentralisation and subsidiarity, and by the definition of the internal administrative structure, creating tailor-made units for specific needs and effective management. Not without significance is also the issue of adequate funding sources, which often directly determines the effectiveness of the implementation of public tasks.

Key words: effectiveness, local government, public tasks 


\section{ЭФФЕКТИВНОСТЬ КАК ДЕТЕРМИНАНТА ДЕЯТЕЛЬНОСТИ ОРГАНОВ ТЕРРИТОРИАЛЬНОГО САМОУПРАВЛЕНИЯ}

\section{Резюме}

На органы территориального самоуправления законодательно наложено обязательство по выполнению общественных задач - собственных задач, цель которых состоит в удовлетворении потребностей сообществ местного самоуправления. В связи с этим органы самоуправления также обязаны предпринимать такие действия и выбирать такие правовые инструменты, чтобы их реализация была эффективной, то есть достигала намеченных целей или, по крайней мере, приближалась к ним. На эффективность работы органов территориального самоуправления влияют: ее выполнение подразделениями территориального деления соответствующего уровня, надлежащее распределение задач и компетенций в соответствии с принципами децентрализации и субсидиарности, создание внутренней административной структуры с созданием подразделений, учитывающих специфические потребности и обеспечивающих эффективное управление. Важной является также проблема соответствующего финансирования, часто непосредственно определяющая эффективность общественных задач.

Ключевые слова: эффективность, территориального самоуправление, общественные задачи 
